\title{
Sensitivity and specificity of diagnostic tests for Lassa fever: a systematic review
}

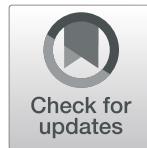

Noah Fongwen Takah ${ }^{1,3^{*}}$, Polina Brangel ${ }^{2}$, Priyanka Shrestha ${ }^{3}$ and Rosanna Peeling ${ }^{3}$

\begin{abstract}
Background: Lassa fever virus has been enlisted as a priority pathogen of epidemic potential by the World Health organization Research and Development (WHO R \& D) Blueprint. Diagnostics play a crucial role in epidemic preparedness. This systematic review was conducted to determine the sensitivity and specificity of Lassa fever diagnostic tests for humans.

Methods: We searched OVID Medline, OVID Embase, Scopus and Web of Science for laboratory based and field studies that reported the performance of diagnostic tests for Lassa fever in humans from 1 January 1990 to 25 January 2019. Two reviewers independently screened all the studies and included only studies that involved the evaluation of a Lassa fever diagnostic test and provided data on the sensitivity and specificity. The quality of the studies was assessed using the QUADAS-2 criteria. Data on the study location, study design, type of sample, index test, reference tests and diagnostic performance were extracted from the studies.

Results: Out of a total of 1947 records identified, 1245 non-duplicate citations were obtained. Twenty-six (26) full-text articles examined which identified 08 studies meeting pre-defined criteria. Only one study was a field evaluation study. The sensitivity and specificity of the point of care (RDT) against the Nikisins qPCR were $91.2 \%(95 \%$ Cl:75.2-97.7) and $86 \%(95 \% \mathrm{Cl}$ : $71.4-94.2)$ at temperatures $18-30^{\circ} \mathrm{C}$, while the sensitivity and specificity of the single IgM ELISA assay against standard RT-PCR were $31.1 \%(95 \% \mathrm{Cl}: 25.6-37)$ and $95.7 \%(95 \% \mathrm{Cl}: 92.8-97.7)$. The sensitivity of the combined ELISA Antigen/IgM assay(against virus isolation), the recombinant IgM/lgG ELISA(against standard RT-PCR), and the IgM/lgG immunoblot(against IFA) were 88\%(95\%Cl:77-95), 25.9\%(95\%Cl:20.8-31.6), and 90.7\%(95\%Cl:84.13-97.27) respectively. The specificity of the combined ELISA Antigen/IgM assay(against virus isolation), the recombinant lgM/lgG ELISA(against standard RT-PCR), and the IgM/lgG immunoblot(against IFA) were 90\%(95\%Cl:88-91), 100\%(95\%Cl:98.2-100), and 96.3\%(95\%Cl:92.2-100) respectively.
\end{abstract}

Conclusion: Lassa fever has assays for antigenaemia, IgM, IgG and PCR detection. The RDT reportedly performed well but more data are needed from other countries and at temperatures above $30^{\circ} \mathrm{C}$. Most combined immunoassays perform better than the single IgM. Multiplex and pan-Lassa assays are needed. More well conducted field studies are needed.

Trial registration: Prospero registration number: CRD42018091585.

Keywords: Lassa, Diagnostics, Sensitivity, Specificity

\footnotetext{
* Correspondence: Noah.Fongwen@lshtm.ac.uk; takahnoah@yahoo.com ${ }^{1}$ International Diagnostics Centre Africa, Addis Ababa, Ethiopia

${ }^{3}$ International Diagnostics Centre, Clinical Research Department, London

School of Hygiene and Tropical Medicine, Keppel Street, London WC1E 7HT,

UK

Full list of author information is available at the end of the article
}

(c) The Author(s). 2019 Open Access This article is distributed under the terms of the Creative Commons Attribution 4.0 International License (http://creativecommons.org/licenses/by/4.0/), which permits unrestricted use, distribution, and reproduction in any medium, provided you give appropriate credit to the original author(s) and the source, provide a link to the Creative Commons license, and indicate if changes were made. The Creative Commons Public Domain Dedication waiver (http://creativecommons.org/publicdomain/zero/1.0/) applies to the data made available in this article, unless otherwise stated. 


\section{Background}

Lassa fever is an acute and potentially fatal hemorrhagic illness caused by the Lassa Fever Virus [1]. The disease has been shown to be endemic in several West African countries including Benin, Guinea, Liberia, Côte d'Ivoire, Mali, Nigeria, and Sierra Leone [2]. The disease is also important in global health security as reflected in the inclusion of the Lassa fever virus in the World Health Organization Research and Development (WHO R\&D) Blueprint as a priority pathogen of epidemic potential [3]. Studies have reported the number of clinical infections to be approximately 100,000-300,000 in West Africa per year, with approximately 5000 deaths $[4,5]$. The recent outbreak of the Lassa epidemic in Nigeria resulted in 327 cases of Lassa fever (324 confirmed and three probable cases) with 72 deaths (case fatality ratio of 22\%) from 1 January to 10 February 2019. The WHO estimates a Lassa case fatality rate of 1 , and $15 \%$ amongst patients hospitalized with severe illness [6].

Lassa fever is a zoonotic infection that can be transmitted to humans through contact with virus-infected rodent excreta via eating rodent-contaminated food, exposure to contaminated objects, and inhalation of tiny particles in the air contaminated with virus-infected rodent excretions [7]. Though not widely observed in epidemic outbreaks, human-to-human transmission can also occur through contact with fluids of infected persons in health care settings through poor infection control measures [8]. Diagnostics play a pivotal role in the control of an outbreak of Lassa fever by: permitting early diagnosis which can necessitate prompt antiviral therapy and reduce morbidity and mortality; assisting in the tracking of community contacts as well as providing the true picture of the epidemic [9-11].

Despite the relevance of diagnostics in the response to Lassa fever outbreaks, the availability of Lassa fever diagnostics is limited for several reasons. Clinically, most Lassa fever patients are asymptomatic, and even when symptoms are present, they can be non-specific [12]. There are also enormous challenges faced in developing an efficacious assay due to the complexity of the Lassa virus sequence diversity [13]. Furthermore, the collection, storage and handling of specimens for Lassa fever requires biosafety level precautions similar to the Ebola virus (Ref). The need for high containment safety requirements and the scarcity of high containment laboratories in many parts of the World may have led to limited Lassa fever assay development and validation studies [14]. However, with the World Health Organization (WHO) call for early diagnostic tests for Lassa [15] and the inclusion of Lassa fever virus as a priority pathogen of epidemic potential in the WHO Research and Development (WHO R \&D) [3, 5], it is necessary to systematically review all the diagnostic tests available, so that gaps in diagnostic research and development can be identified that can guide innovation in R \& D.

Raabe and Koehler conducted a minireview that provides an overview of the currently available diagnostic tests for Lassa [14]. Given that it was minireview, it was clear that the search was not systematic with no quality assessment of the included studies. In addition, the review doesn't provide complete data on the sensitivity and specificity of the diagnostic tests used. Based on the scarcity of systematic reviews with regards to Lassa diagnostics, we conducted this systematic review to determine the sensitivity and specificity of tests available for the diagnosis of Lassa fever in humans. This study will be important in identifying the weaknesses, strengths and applications of the diagnostic assays available for Lassa fever.

\section{Methods}

\section{Search strategy and identification of studies}

This was a systematic review of the diagnostic accuracy of Lassa fever tests used for humans. The review was registered in PROSPERO (Registration number: CRD42018091585) [16] and reported in accordance with the Preferred Reporting Items for Systematic Reviews and Meta-analyses (PRISMA) check list [17]. Literature search strategies were developed by two reviewers (NFT and $\mathrm{PB}$ ) with the help of a librarian at the London School of Hygiene and Tropical Medicine with expertise in systematic review searching. The search strategies are shown in Additional file 1: Table S1 and Additional file 2: Table S2. Two reviewers (NFT and PB) independently searched MEDLINE, EMBASE, the Cochrane Central, Cochrane database for systematic reviews, Scopus, Web of Science, Google Scholar. Additional pertinent citations were identified through bibliographies of retrieved studies. Abstracts were imported into Mendeley and independently screened by two reviewers NFT and PB according to standard inclusion and exclusion criteria. All studies identified for full manuscript review were assessed independently by two reviewers (NFT and $\mathrm{PB})$ against inclusion criteria. Any discrepancies were settled by a round table discussion and consultation with the third reviewer (RP).

\section{Selection criteria}

We included case-control, cross-sectional, cohort studies published between 1 January 1990 and 25 January 2019, with primary purpose of evaluating Lassa fever test accuracy using any clinical specimen type. We also included studies reporting original data from patient specimens in all age groups, studies that reported the laboratory, clinical/field evaluation of a diagnostic tests in humans; studies that reported the sensitivity and specificity with a 
reference standard. We excluded: articles in languages other than English; conference abstracts, comments or review papers; studies only reporting sensitivity or specificity without reference standards; studies using commercially prepared reference panels. We excluded studies not involving human subjects.

\section{Data extraction and quality assessment}

Two reviewers (NFT and PS) independently extracted data and reached agreement on the following variables in the data extraction sheet: study author and year; study location and design; patient age range; name and format of the test; reference test; type and number of specimens tested; type of evaluation (clinical/field vs laboratory); sensitivity and specificity with $95 \%$ confidence intervals; phase of infection during which sample were collected; funding source and any reported conflict of interest. We calculated the 95\% confidence intervals for the studies reporting only point estimates.

Study quality was evaluated using the Quality Assessment of Diagnostic Accuracy Studies (QUADAS)-2 tool [18], which evaluates risk of bias (patient selection, index test, reference standard, and patient flow through) and applicability concerns.

\section{Data synthesis and analysis}

We could not conduct a meta-analysis because: the number of studies for each diagnostic test type was not enough to pool together meaningful data; and the authors were not consistent in the reference standards used in the evaluation of the index tests. Therefore, we carried out only a qualitative synthesis of the studies, taking into consideration the weakness and strengths in the methodologies of evaluation of the diagnostic technologies, that may have influenced the sensitivity and specificity results obtained.

\section{Results}

Study selection and characteristics

A total of 1245 non-duplicate citations were identified, and 26 full-text articles examined which identified 08 studies meeting pre-defined criteria (Fig. 1). Of the included studies, 2 were conducted with patients from $\mathrm{Si}$ erra Leone only, 2 were conducted with patients from Nigeria only, while in 4 studies, patients were enrolled

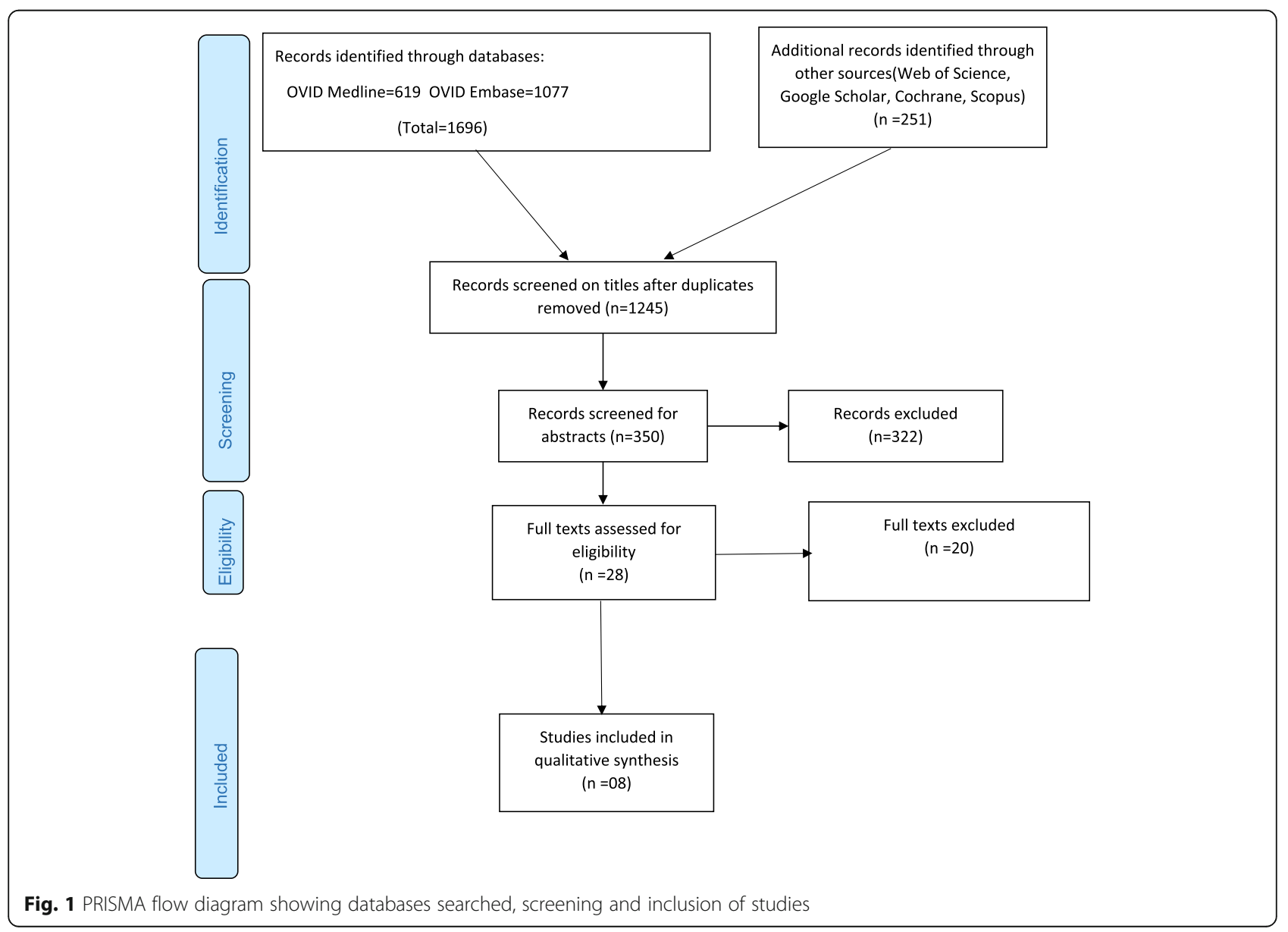


from multiple countries (Nigeria, Sierra Leone and Guinea) and in two studies, samples from patients in Germany were used (Table 1). In most of the studies (05), samples were collected from patients suspected of having Lassa fever. However, one study enrolled the close contacts of patients suspected of having Lassa fever, one study enrolled all patients with fever of unknown origin and hemorrhage, one study enrolled healthy adult blood donors and one study enrolled only Lassa confirmed cases (Table 1).

Only two studies specified the age range of the patients from whom samples were taken. Studies were prospective, cross-sectional or case-control, and predominantly in the laboratory setting (Table 1). Only 01 study compared a rapid diagnostic test (RDT) against an immunoassay and a molecular reference standard (Table 2). This study was conducted in Sierra Leone and involved the field of evaluation of the Recombinant Lassa Virus RDT. Five studies compared immunoassays against virus isolation or molecular reference standards, while two studies compared molecular assays to virus isolation as reference standard (Table 2).

Four (04) out of the six (06) studies that involved the evaluation of antigen and/or antibody assay clearly stated the phase of Lassa infection during which samples were collected from patients and tested. Most of the samples were tested in the acute phase. One study used convalescent samples (Table 3). Two studies did not state their funding source (Table 3). Table 4 shows the excluded full texts, the assays and the reasons for exclusion.

\section{Assessment of quality of studies}

The results of the QUADAS-2 assessment for risk of bias of each study, including summary figures, are shown (Fig. 2). Bias in patient selection was generally attributable to a case-control study design, or from enrolment of highly selected participants such as only patients with laboratory confirmed Lassa fever and healthy adult blood donors. Risk of bias from the index test was most commonly because they were conducted and interpreted with the knowledge of the results of the reference standard. There was an unclear risk of bias in flow and timing because majority (75\%) of studies did not specify the exact time interval between performance of the index and reference assay. In up to $65 \%$ of the studies, there was high risk of bias in the reference standard because virus culture was not used. However, the applicability of the reference standard was of low concern because the target condition that was defined matched the review question.

\section{Diagnostic accuracy of tests for Lassa For rapid diagnostic test (RDT)}

Only one study assessed the accuracy of a rapid test for the diagnosis of Lassa fever [19]. This RDT evaluated is the dipstick recombinant Lassa virus (ReLASV) assay which is a lateral flow immunoassay based on paired monoclonal antibodies to the Josiah strain of the Lassa virus. This study was a prospective cohort study conducted in Sierra Leone and involved the use of 451 serum and plasma samples from patients suspected of having Lassa fever. The reference standards used were

Table 1 Characteristics of included studies: study population and design

\begin{tabular}{|c|c|c|c|c|c|c|}
\hline $\begin{array}{l}\text { Author and } \\
\text { reference }\end{array}$ & $\begin{array}{l}\text { Year } \\
\text { Published }\end{array}$ & Journal & Study Country & Study population & $\begin{array}{l}\text { Study } \\
\text { design }\end{array}$ & $\begin{array}{l}\text { Patient } \\
\text { Age Range } \\
\end{array}$ \\
\hline $\begin{array}{l}\text { Boisen } \\
\text { et al. [19] }\end{array}$ & 2018 & Scientific Reports & Sierra Leone & $\begin{array}{l}\text { Suspected Lassa fever patients and } \\
\text { their contacts }\end{array}$ & $\begin{array}{l}\text { Prospective } \\
\text { cohort }\end{array}$ & $\overline{\text { not stated }}$ \\
\hline $\begin{array}{l}\text { Boisen } \\
\text { et al. [19] }\end{array}$ & 2018 & Scientific Reports & Sierra Leone & $\begin{array}{l}\text { Suspected Lassa fever patients and } \\
\text { their contacts }\end{array}$ & $\begin{array}{l}\text { Prospective } \\
\text { cohort }\end{array}$ & not stated \\
\hline $\begin{array}{l}\text { Bausch } \\
\text { et al. [20] }\end{array}$ & 2000 & Journal of Clinical Virology & Sierra Leone and Guinea & Suspected Lassa fever patients & $\begin{array}{l}\text { Prospective } \\
\text { cohort }\end{array}$ & not stated \\
\hline $\begin{array}{l}\text { Gabriel } \\
\text { et al. [21] }\end{array}$ & 2017 & $\begin{array}{l}\text { PLOS Neglected Tropical } \\
\text { Diseases }\end{array}$ & $\begin{array}{l}\text { Nigeria, Ghana and } \\
\text { Germany }\end{array}$ & Suspected Lassa fever patients & $\begin{array}{l}\text { Prospective } \\
\text { cohort }\end{array}$ & not stated \\
\hline $\begin{array}{l}\text { Ibekwe } \\
\text { et al. [22] }\end{array}$ & 2012 & Nigerian Medical Journal & Nigeria & $\begin{array}{l}\text { Clinically diagnosed patients and } \\
\text { referred suspected patients }\end{array}$ & $\begin{array}{l}\text { Case- } \\
\text { control }\end{array}$ & $\begin{array}{l}11-61 \\
\text { years }\end{array}$ \\
\hline $\begin{array}{l}\text { Meulen } \\
\text { et al. [23] }\end{array}$ & 1998 & $\begin{array}{l}\text { Journal of Clinical } \\
\text { Microbiology }\end{array}$ & $\begin{array}{l}\text { Guinea and Liberia and } \\
\text { Germany (Hamburg) }\end{array}$ & $\begin{array}{l}\text { Patients with fever of unknown } \\
\text { origin and hemorrhage }\end{array}$ & $\begin{array}{l}\text { Cross- } \\
\text { sectional }\end{array}$ & not stated \\
\hline $\begin{array}{l}\text { Emmerich } \\
\text { et al. [24] }\end{array}$ & 2006 & Journal of Clinical Virology & $\begin{array}{l}\text { Nigeria, Liberia, Sierra } \\
\text { Leone and Guinea }\end{array}$ & Healthy adult blood donors & $\begin{array}{l}\text { Cross- } \\
\text { sectional }\end{array}$ & $18-53$ \\
\hline $\begin{array}{l}\text { Olschlager } \\
\text { et al. [25] }\end{array}$ & 2010 & $\begin{array}{l}\text { Journal of Clinical } \\
\text { Microbiology }\end{array}$ & Liberia and Nigeria & Laboratory confirmed Lassa patients & $\begin{array}{l}\text { Cross- } \\
\text { sectional }\end{array}$ & not stated \\
\hline $\begin{array}{l}\text { Trappier } \\
\text { et al. [26] }\end{array}$ & 1993 & $\begin{array}{l}\text { American Journal of Tropical } \\
\text { Medicine and Hygiene }\end{array}$ & Sierra Leone & Suspected Lassa fever patients & $\begin{array}{l}\text { Cross- } \\
\text { sectional }\end{array}$ & not stated \\
\hline
\end{tabular}


Table 2 Characteristics of studies: test name, reference test, type of evaluation and diagnostic performance

\begin{tabular}{|c|c|c|c|c|c|c|c|}
\hline Author & Test Name & Reference Test & $\begin{array}{l}\text { Type of } \\
\text { Samples }\end{array}$ & $\begin{array}{l}\text { Number of } \\
\text { Samples Tested }\end{array}$ & $\begin{array}{l}\text { Type of } \\
\text { evaluation }\end{array}$ & $\begin{array}{l}\text { Sensitivity }(95 \% \\
\text { Cl) }\end{array}$ & $\begin{array}{l}\text { Specificity }(95 \% \\
\text { Cl) }\end{array}$ \\
\hline \multirow[t]{2}{*}{$\begin{array}{l}\text { Boisen } \\
\text { et al }\end{array}$} & \multirow[t]{2}{*}{$\begin{array}{l}\text { Recombinant Lassa Virus Rapid } \\
\text { Diagnostic Test (ReLASV RDT) }\end{array}$} & Nikisins qPCR & $\begin{array}{l}\text { Serum } \\
\text { and } \\
\text { plasma }\end{array}$ & 451 & $\begin{array}{l}\text { Field } \\
\text { evaluation }\end{array}$ & $91.2(75.2-97.7)$ & 86(71.4-94.2) \\
\hline & & ReLASV Ag ELISA & $\begin{array}{l}\text { Serum } \\
\text { and } \\
\text { plasma }\end{array}$ & 451 & $\begin{array}{l}\text { Field } \\
\text { evaluation }\end{array}$ & $94.8(81.3-99.1)$ & 100(88.6-100) \\
\hline $\begin{array}{l}\text { Boisen } \\
\text { et al }\end{array}$ & $\begin{array}{l}\text { Recombinant Lassa Virus Antigen } \\
\text { ELISA(ReLASV Ag ELISA) }\end{array}$ & Nikisins qPCR & $\begin{array}{l}\text { Serum } \\
\text { and } \\
\text { plasma }\end{array}$ & 451 & $\begin{array}{l}\text { Field } \\
\text { evaluation }\end{array}$ & $91.2(75.2-97.7)$ & $86(71.4-94.2)$ \\
\hline \multirow[t]{2}{*}{$\begin{array}{l}\text { Bausch } \\
\text { et al }\end{array}$} & $\begin{array}{l}\text { Combined ELISA Antigen/lgM } \\
\text { assay }\end{array}$ & Virus Isolation & Serum & 305 & Laboratory & $88(77-95)$ & $90(88-91)$ \\
\hline & $\begin{array}{l}\text { Indirect Immunofluorescent } \\
\text { antibody test }\end{array}$ & Virus Isolation & Serum & 305 & $\begin{array}{l}\text { Laboratory } \\
\text { validation }\end{array}$ & $70(57-81)$ & $88(85-90)$ \\
\hline \multirow{2}{*}{$\begin{array}{l}\text { Gabriel } \\
\text { et al }\end{array}$} & $\operatorname{lgM}$ ELISA & Standard RT-PCR & Serum & 270 & Laboratory & $31.1(25.6-37)$ & $95.7(92.8-97.7)$ \\
\hline & Recombinant IgM/lgG ELISA & Standard RT-PCR & Serum & 270 & Laboratory & $25.9(20.8-31.6)$ & 100(98.2-100) \\
\hline $\begin{array}{l}\text { Ibekwe } \\
\text { et al }\end{array}$ & IgM ELISA & Standard RT-PCR & Serum & 72 & Laboratory & $57(41.05-72.95)$ & $77(63.06-90.94)$ \\
\hline $\begin{array}{l}\text { Meulen } \\
\text { et al. }\end{array}$ & IgM/lgG Immunoblot & $\begin{array}{l}\text { Indirect } \\
\text { Immunofluorescent } \\
\text { assay(IFA) }\end{array}$ & Serum & 157 & Laboratory & $\begin{array}{l}90.7(84.13- \\
97.27)\end{array}$ & $96.3(92.2-100)$ \\
\hline $\begin{array}{l}\text { Emmerich } \\
\text { et al }\end{array}$ & Reverse IgG ELISA & IFA & Serum & 643 & Laboratory & 100(99-100) & $99(98-100)$ \\
\hline $\begin{array}{l}\text { Olschlager } \\
\text { et al }\end{array}$ & GPC RT-PCR(Qiagen) & Virus isolation & $\begin{array}{l}\text { Serum } \\
\text { and CSF }\end{array}$ & $\begin{array}{l}77+(1 \mathrm{CSF} \\
\text { sample) }\end{array}$ & Laboratory & 100(99-100) & \\
\hline $\begin{array}{l}\text { Trappier } \\
\text { et al }\end{array}$ & Conventional PCR & Virus Isolation & Serum & 195 & Laboratory & $66(55-77)$ & $78(69.5-84.5)$ \\
\hline
\end{tabular}

Table 3 Characteristics of included studies cont'd: phase of infection and funding source

\begin{tabular}{|c|c|c|c|}
\hline $\begin{array}{l}\text { Author } \\
\text { Last }\end{array}$ & Test Name & Phase of infection & Funding source \\
\hline $\begin{array}{l}\text { Boisen } \\
\text { et al }\end{array}$ & $\begin{array}{l}\text { Recombinant Lassa Virus Rapid } \\
\text { Diagnostic Test (ReLASV RDT) }\end{array}$ & Acute phase & $\begin{array}{l}\mathrm{NIH} \text { (National Institute for Health). Possible } \\
\text { conflict of interest with Viral Hemorrrhagic } \\
\text { fever Consortium. }\end{array}$ \\
\hline $\begin{array}{l}\text { Boisen } \\
\text { et al }\end{array}$ & $\begin{array}{l}\text { Recombinant Lassa Virus Antigen ELISA } \\
\text { (ReLASV Ag ELISA) }\end{array}$ & & $\begin{array}{l}\mathrm{NIH} \text { (National Institute for Health). Possible } \\
\text { conflict of interest with Viral Hemorrrhagic } \\
\text { fever Consortium. }\end{array}$ \\
\hline \multirow{2}{*}{$\begin{array}{l}\text { Bausch } \\
\text { et al }\end{array}$} & Combined ELISA Antigen/IgM assay & \multirow{2}{*}{$\begin{array}{l}\text { Acute phase. Convalescent samples collected but } \\
\text { data on testing not given. }\end{array}$} & \multirow{2}{*}{$\begin{array}{l}\text { American Association of Schools of Public } \\
\text { Health (AASPH) \& Tulane University }\end{array}$} \\
\hline & $\begin{array}{l}\text { Indirect Immunofluorescent antibody } \\
\text { test }\end{array}$ & & \\
\hline \multirow{2}{*}{$\begin{array}{l}\text { Gabriel } \\
\text { et al }\end{array}$} & $\operatorname{IgM}$ ELISA & \multirow[t]{2}{*}{ Not clear } & \multirow[t]{2}{*}{ European Fund for regional development } \\
\hline & $\operatorname{lgM} / \operatorname{lgG}$ ELISA & & \\
\hline $\begin{array}{l}\text { lbekwe } \\
\text { et al }\end{array}$ & IgM ELISA & Acute phase & No funding source \\
\hline $\begin{array}{l}\text { Meulen } \\
\text { et al. }\end{array}$ & IgM/lgG Immunoblot & Not clear & Not stated \\
\hline $\begin{array}{l}\text { Emmerich } \\
\text { et al }\end{array}$ & Reverse IgG ELISA & Convalescent samples (from survivors) & $\begin{array}{l}\text { Bundesamt f"ur Wehrtechnik und } \\
\text { Beschaffung }\end{array}$ \\
\hline $\begin{array}{l}\text { Olschlager } \\
\text { et al }\end{array}$ & GPC RT-PCR(Qiagen) & Not clear & $\begin{array}{l}\text { Bundesamt f"ur Wehrtechnik und } \\
\text { Beschaffung }\end{array}$ \\
\hline $\begin{array}{l}\text { Trappier } \\
\text { et al }\end{array}$ & Conventional PCR & Not clear & Not stated \\
\hline
\end{tabular}


Table 4 Excluded full texts and the reasons for exclusion

\begin{tabular}{|c|c|c|}
\hline Study & Assay & Reason \\
\hline $\begin{array}{l}\text { 1- Fukuma et al, } \\
2011[27]\end{array}$ & Reverse Transcription LAMP & No data on sensitivity and specificity. Just talks about assay development \\
\hline $\begin{array}{l}\text { 1- Fukushi et al, } \\
2012[28]\end{array}$ & Serological assays & Review. No data on performance \\
\hline $\begin{array}{l}\text { 3- Pang et al, } \\
2014 \text { [29] }\end{array}$ & $\begin{array}{l}\text { Multiplex one step Real-Time Taqman qRT- } \\
\text { PCR }\end{array}$ & No data on sensitivity and specificity given. Not a lab or field evaluation. \\
\hline $\begin{array}{l}\text { 4- Das et al, } \\
2015 \text { [30] }\end{array}$ & Multiplex PCR/LDR assay & Not an evaluation. No data on sensitivity and specificity \\
\hline $\begin{array}{l}\text { 5- Jones A et al, } \\
2011 \text { [31] }\end{array}$ & Handheld multiplex POC diagnostics & No data on sensitivity and specificity \\
\hline $\begin{array}{l}\text { 6- Trombley et al, } \\
2010[32]\end{array}$ & RT-TaqMan PCR & Not an evaluation study. No data on sensitivity and specificity \\
\hline $\begin{array}{l}\text { 7- Drosten et al, } \\
2002[33]\end{array}$ & SYBR-green real time RT-PCR & Not a lab or field evaluation. \\
\hline $\begin{array}{l}\text { 8- Bukbuk et al, } \\
2014[34]\end{array}$ & Recombinant NP(rNP) IgG ELISA & No data on sensitivity and specificity \\
\hline $\begin{array}{l}\text { 9- Barber et al, } \\
1990 \text { [35] }\end{array}$ & Recombinant ELISA & Not evaluated in humans. No data on sensitivity and specificity \\
\hline $\begin{array}{l}\text { 10- Li et al, } \\
2009[36]\end{array}$ & $\begin{array}{l}\text { Fluorescent microbeads based multiplex } \\
\text { assay }\end{array}$ & No data on performance \\
\hline $\begin{array}{l}\text { 11- Saijo et al, } \\
2007 \text { [37] }\end{array}$ & Ag-Capture ELISA & No data on the performance \\
\hline $\begin{array}{l}\text { 12- Salvato et al, } \\
2018 \text { [38] }\end{array}$ & & Review \\
\hline $\begin{array}{l}\text { 13- Satterly et al, } \\
2016 \text { [39] }\end{array}$ & Ag and IgM Capture(MAGPIX) & \\
\hline $\begin{array}{l}\text { 14- Olschlager et al, } \\
2012 \text { [40] }\end{array}$ & RT-PCR/hybridization assay & No data on sensitivity and specificity \\
\hline $\begin{array}{l}\text { 15- Vieth et al, } \\
2007[41]\end{array}$ & RT-PCR & Not an evaluation study \\
\hline $\begin{array}{l}\text { 16- Leski et al, } \\
2009[42]\end{array}$ & High Density Resequencing microarray & No data on sensitivity and specificity. \\
\hline $\begin{array}{l}\text { 17- O'Hearn et al, } \\
2016 \text { [43] }\end{array}$ & $\lg G(M A G P I X)$ & No data on sensitivity and specificity \\
\hline $\begin{array}{l}\text { 18- Demby et al, } \\
1994 \text { [44] }\end{array}$ & Standard RT-PCR & Not an evaluation study \\
\hline $\begin{array}{l}\text { 19- Sebba D et al, } \\
2018 \text { [45] }\end{array}$ & $\begin{array}{l}\text { Multiplex POC test for Lassa, Ebola } \\
\text { and Malaria }\end{array}$ & $\begin{array}{l}\text { None of the } 276 \text { clinical samples tested with the 3-plex assay were independently } \\
\text { tested for LASV. }\end{array}$ \\
\hline $\begin{array}{l}\text { 20- Koehler et al, } \\
2018[46]\end{array}$ & $\begin{array}{l}\text { Highly Multiplex Broad Pathogen } \\
\text { detection assay }\end{array}$ & No data on sensitivity and specificity. \\
\hline
\end{tabular}

Recombinant Antigen ELISA (Enzyme Linked Immunosorbent Assay) and the Nikisins qPCR (quantitative polymerase chain reaction). Compared with the ReLASV antigen ELISA as the standard, the sensitivity and specificity of the test were 94.1\%(95\%CI:78.9-99.0\%) and $83.7 \%(68.7-92.6 \%)$ respectively at temperatures $18-30{ }^{\circ} \mathrm{C}$. Meanwhile, compared with the Nikisins qPCR, the sensitivity and specificity were $91.2 \%(95 \% \mathrm{CI}$ : 75.2-97.7) and $86 \%(95 \% \mathrm{CI}: 71.4-94.2)$ respectively at temperatures $18-30{ }^{\circ} \mathrm{C}$. Visual interpretation was possible within $15-25 \mathrm{~min}$.

\section{For immunoassays}

Six studies evaluated the performance of immunoassays against different reference standards. Three of the studies assessed the performance of combined immunoassays [19-24]. The three combined immunoassays and their reference standards include: The combined ELISA Antigen/IgM assay against virus culture [20]; the combined IgM/IgG ELISA against standard RT-PCR [21]; the combined IgM/IgG Immunoblot against Indirect Immunofluorescent assay(IFA) [23]. 

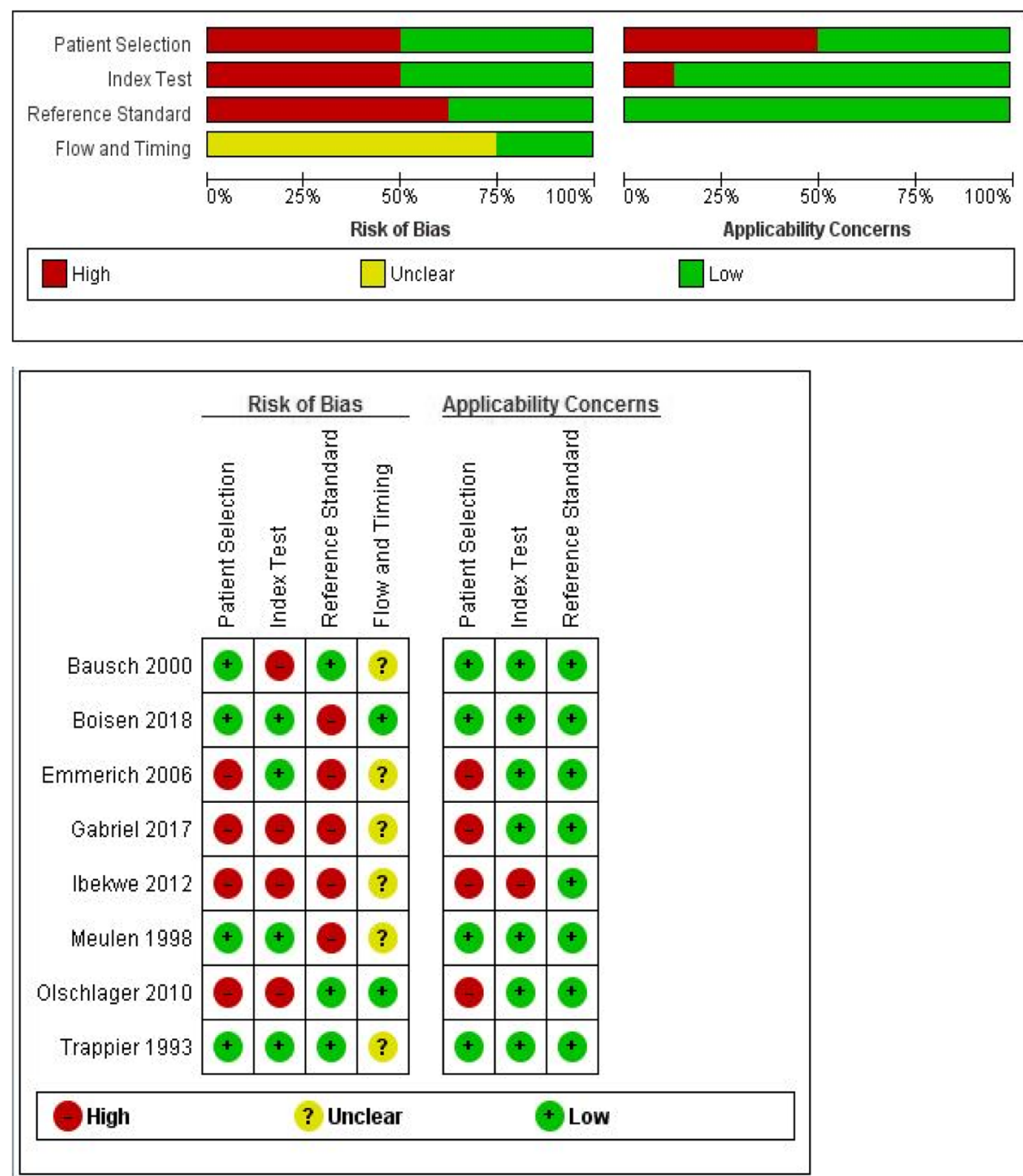

Fig. 2 Results of the quality assessment of studies using the QUADAS-2 tool

The sensitivity of the combined ELISA Antigen/IgM assay, the IgM/IgG ELISA, and the IgM/IgG immunoblot were $88 \%((95 \%$ CI:77-95), 25.9\%(95\%CI:20.8-31.6), and $90.7 \%(95 \% \mathrm{CI}: 84.13-97.27)$ respectively. The specificity of the combined ELISA Antigen/IgM assay, the IgM/IgG ELISA, and the IgM/IgG immunoblot were 90\%((95\%CI:88-91), 100\%(95\%CI:98.2-100), and 96.3\%( 95\%CI: 92.2-100) respectively. In total, the studies involving the evaluation of the combined immunoassays used 732 serum samples.

Three studies evaluated a single immunoassay against their reference standards as well. These single immunoassays include: The Recombinant Antigen ELISA assay against the Nikisins qPCR [19]; the IgM ELISA against RT-PCR [22]; and the Reverse IgG ELISA against IFA [24]. The sensitivity of the Recombinant Ag ELISA, IgM ELISA and Reverse IgG ELISA were 91.2\%(95\%CI:75.297.7), 57\%(95\%CI:11.05-72.95) and 100\%(95\%CI:99-
100) respectively. The specificity of the Recombinant Ag ELISA, IgM ELISA and Reverse IgG ELISA were 86\%(95\%CI:71.4-94.2), 77\%(95\%CI:63.06-90.94) and 99\%(95\%CI:98-100) respectively. The studies that evaluated the single immunoassays used a total of 1166 serum samples.

Gabriel et al [21] also evaluated the single IgM ELISA assay alongside the evaluation of the combined IgM/IgG assay. The sensitivity and specificity of the single IgM assay against RT-PCR from this study were $31.1(95 \% \mathrm{CI}$ : 25.6-37) and 95.7(95\%CI: 92.8-97.7) respectively.

\section{For molecular tests}

Two studies reported the diagnostic performance of molecular assays $[25,26]$. The molecular assays evaluated in the laboratory were the Glycoprotein Precursor (GPC) gene specific RT-PCR assay [25] and the conventional PCR [26]. The GPC RT-PCR/2007 assay was validated 
with 77 serum samples and 1 CSF sample from patients with laboratory- confirmed Lassa fever. Compared with virus culture, the sensitivity of the assay was $100 \%(95 \% \mathrm{CI}$ : 99-100). However, the sensitivity and specificity of the conventional PCR assay were 66\%(95\%CI: $55-77)$ and $78 \%(95 \%$ CI:69.5-84.5) respectively. No study evaluated the diagnostic performance of a multiplex assay for detection of many Lassa fever strains.

\section{Discussion}

\section{Study findings}

The findings from this first ever conducted systematic review on the diagnostic performance of Lassa fever assays show that of the studies included, the authors reported different assays available for the detection of the Lassa fever virus ranging from a point of care recombinant antigen test, combined and single ELISA immunoassays and molecular assays. The performance of combined immunoassays was higher than the single IgM ELISA assays, making the use of single immunoassays of IgM ELISA unsuitable for the screening of Lassa fever patients. Furthermore, we found no study that evaluated and reported the sensitivity and specificity of a multiplex assay for detection of the different strains of Lassa virus in West Africa.

\section{Reference standards for Lassa fever diagnosis}

In our study, we found that different reference standards were used in the evaluation of diagnostic performance of Lassa tests. This variation in reference standards ranging from immunoassays to real time RT-PCR assays is a clear indication that there is still no uniformly accepted clinical reference standard besides virus culture. Even though the high sensitivity and specificity of real time RT-PCR assays make them suitable for this role [14], there is need for more data on the clinical performance of other molecular assays such as the RT-Taqman PCR and the Nikisins qPCR. Immunoassays such as the antigen capture ELISA assays may be unsuitable reference standards due to the short period of antigenaemia during a Lassa virus infection. There is also evidence to suggest that the presence of IgM may either clear or mask the detection of antigens for Lassa in blood [20].

\section{Serum antigenaemia and antibody variation and the performance of Lassa diagnostic tests}

Typically, serum antigen levels peak during the first week of illness with Lassa and are later replaced by IgM during the second week [20]. IgG levels start rising during the third week and remain positive even during the convalescent period [20]. In our included studies, the authors used samples collected from acutely ill patients, convalescent patients or did not clearly state the phase of infection during which samples were collected. It is very important for researchers that are evaluating the performance of serological assays to have this variation in serum antigens and antibodies in mind because the timing of testing can affect the performance of serological assays due to the variation in the serum antigen and antibody levels.

\section{The use of a point of care (POC) RDT for Lassa}

The WHO call for rapid tests for Lassa has played a key role to incentivize diagnostic development for Lassa [15]. Even though a definitive diagnosis of Lassa is only possible in reference laboratories, point of care testing using RDTs has the advantage of reducing delays in testing and treating, as well as facilitating a better understanding of the nature of an outbreak [47]. Despite the urgent need for RDTs, our study identified only one RDT under evaluation: The Recombinant Lassa fever virus antigen test, which is a lateral flow immunoassay against the Josiah strain (lineage IV) of the Lassa fever virus. The performance of this assay was comparable to molecular tests such as qPCR and RT-PCR at temperatures $18-30^{\circ} \mathrm{C}$. These results are very promising given that at such level of performance, very few results will be false positives, making it very useful in improving the case definition during an outbreak [14]. Furthermore, having such a highly performant assay would greatly enhance appropriate patient enrollment for vaccine and therapeutic clinical studies [14].

Despite the high performance of the RDT, there are important concerns that may suggest the findings should be interpreted with caution. Firstly, there is not enough evidence to support the use of the Nikisins qPCR and Recombinant Antigen ELISA as the gold standards. Secondly, the performance of the test above $30{ }^{\circ} \mathrm{C}$ was not evaluated and given that Lassa fever occurs in humid areas with high temperatures (approaching $40^{\circ} \mathrm{C}$ or more) such as in Northern Nigeria, these environmental conditions should be taken into consideration if the test is intended for use in such areas [5]. Thirdly, the assay was limited to the Josiah strain of the Lassa virus. Taking the diversity of the Lassa fever virus across West Africa into consideration, more work is needed to design and evaluate an RDT that can detect all Lassa strains. However, it has been reported that such a pan-Lassa virus assay is currently being evaluated in Nigeria [31]. Future efforts are also geared towards the development of a point of care multiplex molecular assay using the SHERLOCK (Specific High Enzymatic Reporter Unlocking) platform that can ensure even more precise testing with earlier detection as compared with the lateral flow immunoassay [48]. For such a point of care multiplex assay, more emphasis should be given to reducing the cost, to ensure affordability and high uptake by the governments of developing countries in West Africa. 
Antigen and antibody ELISA assays for detection of Lassa For Serological assays to be useful in screening, etiological diagnosis, and sero-epidemiological studies of Lassa fever, they must be must be sensitive, specific and reliable, since a misdiagnosis can misguide public health interventions to control an outbreak and possibly trigger panic in the population [14]. The sensitivity and specificity of the single IgM ELISA assay evaluated were low using the same reference standard in two different studies conducted in Nigeria. Gabriel et al didn't clearly state the phase of infection during which serum samples were collected and tested, while Ibekwe et al clearly included cases within 4 weeks of suspected infection. Even though Ibekwe et al were precise about their inclusion criteria, they did not stratify the number patients tested in each week after recruitment. Since IgM antibodies become detectable in the second week of infection [49], it is possible that the low performance of the IgM assay may have been due to the inclusion and testing of mainly patients in the first week of infection.

To improve on the performance of single antibody ELISA assays, Emmerich et al developed and evaluated the reverse ELISA techniques [24]. The sensitivity and specificity of the reverse IgG ELISA using Indirect Immunofluorescence assay (IFA) as gold standard were as high as RT-PCR assays. This high performance could be due to the modifications in the design of the assay that ensure a more direct binding of antigen-antibody complexes than in indirect ELISA assays [24]. The high performance of the reverse ELISA assays can be disputed based on the methodological flaws of the study. Using IFA as the gold standard, and the use of serum samples from healthy blood donors may suggest that the findings from the study are conservative and should be interpreted with care. Therefore, further studies evaluating the performance of the reverse IgG assay with serum from patients suspected of having Lassa at different stages in their clinical presentation are needed to either confirm or refute the findings.

The use of recombinant antigen detection of Lassa fever virus has improved on the development and access of Lassa fever diagnostics by obviating the need for BSL-4 facilities [28]. The Recombinant antigen ELISA tests showed a high sensitivity comparable with molecular testing. This higher performance of antigen tests compared to antibody tests has been linked to the high antigenemia in Lassa infection [50]. However, it should be noted that the short duration of antigenemia means antigens can become undetectable despite high levels of viremia in Lassa fever patients, thereby markedly reducing the performance of the antigen assays [14, 48]. Since antibodies have a longer duration in blood, one way that has been suggested to overcome this challenge has been to use combined antigen/antibody ELISA assays. This could explain why the combined antigen/IgM assay evaluated by Bausch et al had a higher performance than the single recombinant assay.

\section{For molecular assays}

Several molecular assays have been developed for Lassa fever detection but only the performance of the GPC RT-PCR have been evaluated recently. The performance of the RT-PCR assay was very close to that of the virus culture used as gold standard. This can explain why RT-PCR assays have been used as clinical standard for in some Lassa fever studies [14]. The stark difference in sensitivity between conventional PCR and gene specific RT-PCR can be due to the high variability of the Lassa virus which limited the ability of the conventional PCR to reliably detect all strains. With the gene specific RT-PCR, a revised protocol which considered the $62 \mathrm{~S}$ RNA (ribonucleic acid) sequence from all Lassa endemic countries was used. This greatly improved the sensitivity of the RTPCR. The main caveat of the study evaluating the performance of the gene specific RT-PCR is the small sample size used in the laboratory evaluation. Studies that are conducted in the field with larger sample sizes will be needed to confirm the findings. RT-PCR assays are widely used in screening samples and in reference laboratory settings in the diagnosis of Lassa, but the level of sophistication and training limit their use in peripheral health care settings. To overcome this limitation, a new RT-LAMP is currently under development, but a field evaluation is still yet to be carried out to provide data on its performance [27].

The main challenge with nucleic acid detection assays for Lassa is the genetic diversity which may have a profound negative effect on their performance even if there is minimal variations in just one primer [51]. However, by re-designing the assays after identification of mismatches, the performance of RT-PCR assays has been optimized. Furthermore, multiplex assays such as the RT-Taqman PCR and the PCR/LDR assays that detect several strains of Lassa alone or in combination with enzyme hybridization, as well as many other hemorrhagic viruses have been developed [29, 30]. Even though none of these multiplex assays have been evaluated in the field, their use in epidemic response will be crucial in screening patients in areas where many hemorrhagic fever viruses can occur and in which many patients may present with fever of unknown origin.

\section{Strengths and limitations}

Our systematic review has several strengths and some limitations. Many databases were searched using a 
clearly defined search strategy. There was independent search, screening and extraction of data from articles, thereby reducing the bias in the selection of articles for inclusion. We also assessed the quality of included studies, through which weaknesses in the methodology of included studies were identified so that lessons can be learnt by other investigators as they design and conduct any future diagnostic studies for Lassa. The main limitation we could identify in our study was that we targeted only studies evaluating diagnostics for humans even though Lassa fever is a zoonotic infection [7]. Therefore, our study does not provide any information on the use of diagnostics for Lassa in animals. Despite this limitation, our study is the first of its kind involving the review of the evidence on a clearly formulated research question using systematic and explicit methods to identify, select and critically appraise relevant primary research, and to extract data from the studies on Lassa fever diagnostics. This high level of transparency and robustness suggests the level of bias is very low.

\section{Conclusion}

Lassa fever has assays for antigenaemia, IgM, IgG and PCR detection. The RDT we identified in our study, reportedly performed well but more data are needed from other countries and at temperatures above $30^{\circ} \mathrm{C}$. Combined immunoassays perform better than the single IgM immunoassays. More data are needed to establish a clinical reference standard for Lassa fever diagnosis. Multiplex and pan-Lassa assays are needed for Lassa. More well conducted field and laboratory studies with a clear description of the patient/sample flow and timing are needed in future.

\section{Additional files}

Additional file 1: Table S1. Medline search strategy. (DOCX 15 kb)

Additional file 2: Table S2. Embase search strategy. (DOCX 13 kb)

\section{Abbreviations}

Ag: Antigen; ELISA: Enzyme Linked Immunosorbent Assay; IFA: Indirect Immunofluorescent Assay; LAMP: Loop-mediated Isothermal Amplification; qPCR: Quantitative PCR; QUADAS: Quality Assessment tool for Diagnostic Accuracy Studies; RDT: Rapid diagnostic test; ReELISA: Recombinant Enzyme Linked Immunosorbent Assay; RNA: Ribonucleic acid; RT-PCR: Real Time Polymerase Chain Reaction

\section{Acknowledgements}

We would like to acknowledge the assistance of the Librarian of the London School of Hygiene and Tropical Medicine in the developing the search strategy for this study.

\section{Authors' contributions}

NFT and PB designed the study, with input from RP in building search algorithm and retrieving articles. All authors contributed to study optimization. NFT, PB and PS identified and extracted data. NFT wrote the manuscript with input from PB, PS and RP. All authors read and approved the final manuscript.

\section{Funding}

This research was funded by EPSRC IRC in Early-Warning Sensing Systems for Infectious Diseases (i-sense) EP/K031953/1. The funding body had no role in the study design, collection, analysis, interpretation of data and in writing the manuscript.

\section{Availability of data and materials}

All the data used in this study have provided in the tables submitted.

Ethics approval and consent to participate

Not applicable.

\section{Consent for publication}

Not applicable.

\section{Competing interests}

The authors declare that they have no competing interests.

\section{Author details}

${ }^{1}$ International Diagnostics Centre Africa, Addis Ababa, Ethiopia. ${ }^{2}$ London Centre for Nanotechnology, University College London, London, UK. ${ }^{3}$ International Diagnostics Centre, Clinical Research Department, London School of Hygiene and Tropical Medicine, Keppel Street, London WC1E 7HT, UK.

Received: 14 February 2019 Accepted: 30 June 2019

Published online: 19 July 2019

\section{References}

1. Hallam HJ, Hallam S, Rodriguez SE, Barrett ADT, Beasley DWC, Chua A, et al. Baseline mapping of Lassa fever virology, epidemiology and vaccine research and development. NPJ Vaccines. 2018;3:11.

2. Richmond JK, Baglole DJ. Lassa fever: epidemiology, clinical features, and social consequences. BMJ. 2003;327(7426):1271-5.

3. World Health Organization(WHO). The WHO research and development blueprint:list of priority diseases. https://www.who.int/medicines/ebolatreatment/WHO-list-of-top-emerging-diseases/en/. Accessed 10 Dec 2015.

4. Ogbu O, Ajuluchukwu E, Uneke CJ. Lassa fever in west African sub-region: an overview. J Vector Borne Dis. 2007:44:1-11.

5. The Lancet Infectious Diseases. Lassa fever and global health security. Lancet Infect Dis. 2018;18:357.

6. World Health Organisation(WHO). Emergencies preparedness, response. Lassa fever-Nigeria. 2019. https://www.who.int/csr/don/14-february-2019lassa-fever-nigeria/en/.

7. Agbonlahor DE, Erah A, Agba IM, Oviasogie FE, Ehiaghe AF, Wankasi M, et al. Prevalence of Lassa virus among rodents trapped in three SouthSouth States of Nigeria. J Vector Borne Dis. 2017;54(2):146-50.

8. Effiong EB. Epidemiology and control of Lassa fever. Inter Ped Dent Open Acc J. 2018;1(4):IPDOAJ.MS.ID.000116.

9. Bausch DG, Hadi CM, Khan SH, Lertora JJ. Review of the literature and proposed guidelines for the use of oral ribavirin as postexposure prophylaxis for Lassa fever. Clin Infect Dis. 2010;51:1435-41.

10. Hamblion EL, Raftery P, Wendland A, Dweh E, Williams GS, George RNC, et al. The challenges of detecting and responding to a Lassa fever outbreak in an Ebola-affected setting. Int J Infect Dis. 2018;66: 65-73

11. Fatiregun AA, Isere EE. Epidemic preparedness and management: a guide on Lassa fever outbreak preparedness plan. Niger Med J. 2017:58(1):1-6.

12. Yun NE, Walker DH. Pathogenesis of Lassa fever. Viruses. 2012:4:2031-48.

13. Lassa Fever Research and Development ( R \& D ) Roadmap. 2018;1-18. https://www.who.int/blueprint/priority-diseases/key-action/LassaFever_ Draft_Roadmap_publiccomment_MAY2018.pdf?ua=1.

14. Raabe V, Koehler J. Laboratory diagnosis of Lassa fever. J Clin Microbiol. 2017:55:1629-37.

15. World Health Organization(WHO). The WHO calls for early diagnostic tests for Lassa. https://www.who.int/emergencies/diseases/lassa-fever/earlydiagnostic-lassa-fever/en. Accessed Apr 2016

16. Brangel $\mathrm{P}$, Fongwen $\mathrm{N}$. International prospective register of systematic reviews diagnostic accuracy of tests to detect lassa fever virus : a systematic review of the literature and meta-analysis; 2018. p. 1-3. http://www.crd.york. ac.uk/PROSPERO/display_record.php?ID=CRD42018091585 
17. Moher D, Liberati A, Tetzlaff J, Altman DG. Preferred reporting items for systematic reviews and meta-analyses : the Prisma statement. Ann Intern Med. 2009;151(4):264-9.

18. Whiting PF, Rutjes AWS, Westwood ME, Mallett S, Deeks JJ, Reitsma JB, et al. QUADAS-2: a revised tool for the quality assessment of diagnostic accuracy studies. Ann Intern Med. 2011;155(8):529-36.

19. Boisen ML, Hartnett JN, Shaffer JG, Goba A, Momoh M, Sandi JD, et al. Field validation of recombinant antigen immunoassays for diagnosis of Lassa fever. Sci Rep. 2018;8:5939.

20. Bausch DG, Rollin PE, Demby AH, Coulibaly M, Kanu J, Conteh AS, et al. Diagnosis and clinical virology of Lassa fever as evaluated by enzyme-linked immunosorbent assay, indirect fluorescent- antibody test, and virus isolation. J Clin Microbiol. 2000;38:2670-7.

21. Gabriel M, Adomeh DI, Ehimuan J, Oyakhilome J, Omomoh EO, Ighodalo Y, et al. Development and evaluation of antibody-capture immunoassays for detection of Lassa virus nucleoprotein-specific immunoglobulin $\mathrm{M}$ and $\mathrm{G}$. PLoS Negl Trop Dis. 2018;12(3):e0006361.

22. Ibekwe TS, Nwegbu MM, Asogun D, Adomeh DI, Okokhere PO. The sensitivity and specificity of Lassa virus IgM by ELISA as screening tool at early phase of Lassa fever infection. Niger Med J. 2012;53:196-9.

23. Ter Meulen J, Koulemou K, Wittekindt T, Windisch K, Strigl S, Conde S, et al. Detection of Lassa virus antinucleoprotein immunoglobulin $\mathrm{G}(\mathrm{lgG})$ and $\lg \mathrm{M}$ antibodies by a simple recombinant immunoblot assay for field use. J Clin Microbiol. 1998;36:3143-8.

24. Emmerich P, Thome-Bolduan C, Drosten C, Gunther S, Ban E, Sawinsky I, et al. Reverse ELISA for IgG and IgM antibodies to detect Lassa virus infections in Africa. J Clin Virol. 2006;37:277-81.

25. Ölschläger $S$, Lelke $M$, Emmerich $P$, Panning $M$, Drosten $C$, Hass $M$, et al. Improved detection of Lassa virus by reverse transcription-PCR targeting the 5' region of S RNA. J Clin Microbiol. 2010;48:2009-13.

26. Trappier SG, Conaty AL, Farrar BB, Auperin DD, McCormick JB, Fischer-Hoch SP. Evaluation of the polymerase chain reaction for diagnosis of Lassa virus infection. Am J Trop Med Hyg. 1993;49(2):214-21.

27. Fukuma A, Kurosaki Y, Morikawa Y, Grolla A, Feldmann H, Yasuda J. Rapid detection of Lassa virus by reverse transcription-loop-mediated isothermal amplification. Microbiol Immunol. 2011;55(1):44-50.

28. Fukushi S, Tani H, Yoshikawa T, Saijo M, Morikawa S, F S, et al. Serological assays based on recombinant viral proteins for the diagnosis of arenavirus hemorrhagic fevers. Viruses. 2012;4(10):2097-114.

29. Pang Z, Li A, Li J, Qu J, He C, Zhang S, et al. Comprehensive multiplex onestep real-time TaqMan qRT-PCR assays for detection and quantification of hemorrhagic fever viruses. PLoS One. 2014;9:e95635.

30. Das S, Rundell MS, Mirza AH, Pingle MR, Shigyo K, Garrison AR, et al. A multiplex PCR/LDR assay for the simultaneous identification of category a infectious pathogens: agents of viral hemorrhagic fever and Variola virus. PLoS One. 2015;10:e0138484.

31. Jones A, Boisen M, Radtkey R, Blidner R, Goba A, Pitts K, et al. Development of a handheld multiplex point of care diagnostic for differentiation of Lassa fever, Dengue fever and Ebola Hemorrhagic Fever. 2011. https://www.nano. com/downloads/Nanomix_AACC_poster_Abstract.pdf.

32. Trombley AR, Wachter L, Garrison J, Buckley-Beason VA, Jahrling J, Hensley $L E$, et al. Comprehensive panel of real-time TaqMan polymerase chain reaction assays for detection and absolute quantification of filoviruses, arenaviruses, and New World hantaviruses. Am J Trop Med Hyg. 2010;82: 954-60.

33. Drosten C, Gottig S, Schilling S, Asper M, Panning M, Schmitz H, et al. Rapid detection and quantification of RNA of Ebola and Marburg viruses, Lassa virus, Crimean-Congo hemorrhagic fever virus, Rift Valley fever virus, dengue virus, and yellow fever virus by real-time reverse transcription-PCR. J Clin Microbiol 2002:40(7):2323-30

34. Bukbuk DN, Fukushi S, Tani H, Yoshikawa T, Taniguchi S, Iha K, et al. Development and validation of serological assays for viral hemorrhagic fevers and determination of the prevalence of Rift Valley fever in Borno State, Nigeria. Trans R Soc Trop Med Hyg; 2014;108:768-73.

35. Barber GN, Clegg JC, Lloyd G, G.N. B, J.C.S. C. Expression of the Lassa virus nucleocapsid protein in insect cells infected with a recombinant baculovirus: application to diagnostic assays for Lassa virus infection. J Gen Virol 1990;71 ( Pt 1):19-28.

36. Li J, Zhang S, Zhang Q, Liu Q, Wei Y, Li C, et al. Fluorescent microbeadsbased multiplex detection of IgM antibodies to pathogens caused viral hemorrhagic fever. Chin J Exper Clin Virol 2009;23:149-51.
37. Saijo M, Georges-Courbot MC, Marianeau P, Romanowski V, Fukushi S, Mizutani T, et al. Development of recombinant nucleoprotein-based diagnostic systems for lassa fever. Clin Vaccine Immunol 2007 ; 14(9):1182-9.

38. Salvato MS, Lukashevich IS, Medina-Moreno S, Zapata JC. Diagnostics for Lassa Fever: Detecting Host Antibody Responses. Methods Mol Biol 2018; 1604:79-88.

39. Satterly NG, Voorhees MA, Ames AD, Schoepp RJ. Comparison of MagPix Assays and Enzyme-Linked Immunosorbent Assay for Detection of Hemorrhagic Fever Viruses. J Clin Microbiol 2017;55:68-78.

40. Olschlager S, Gunther S. Rapid and specific detection of Lassa virus by reverse transcription-PCR coupled with oligonucleotide array hybridization. J Clin Microbiol 2012;50:2496-9.

41. Vieth S, Drosten C, Lenz O, Vincent M, Omilabu S, Hass M, et al. RT-PCR assay for detection of Lassa virus and related Old World arenaviruses targeting the L gene. Trans R Soc Trop Med Hyg 2007:101:1253-64.

42. Leski TA, Lin B, Malanoski AP, Wang Z, Long NC, Meador CE, et al. Testing and validation of high density resequencing microarray for broad range biothreat agents detection. PloS one 2009;4:e6569.

43. O'Hearn AE, Voorhees MA Fetterer DP, Wauquier N, Coomber MR, Bangura $\mathrm{J}$, et al. Serosurveillance of viral pathogens circulating in West Africa. Virol J $2016 ; 13(1): 163$

44. Demby AH, Chamberlain J, Brown DW, Clegg CS. Early diagnosis of Lassa fever by reverse transcription-PCR. J Clin Microbiol 1994;32:2898-903.

45. Sebba D, Lastovich AG, Kuroda M, Fallows E, Johnson J, Ahouidi A, et al. A point-of-care diagnostic for differentiating Ebola from endemic febrile diseases. Sci Transl Med 2018;10(471)

46. Koehler JW, Douglas CE, Minogue TD. A highly multiplexed broad pathogen detection assay for infectious disease diagnostics. PLoS Negl Trop Dis 2018; 12:e0006889.

47. Dhillon RS, Srikrishna D, Garry RF. Early detection of Lassa fever: the need for point-of-care diagnostics. Lancet Infect Dis. 2018;18:601-2.

48. Gootenberg JS, Abudayyeh OO, Kellner MJ, Joung J, Collins JJ, Zhang F. Multiplexed and portable nucleic acid detection platform with Cas13, Cas12a, and Csm6. Science. 2018;360(6387):439-44

49. Johnson KM, McCormick JB, Webb PA, Smith ES, Elliott LH, King IJ. Clinical virology of Lassa fever in hospitalized patients. J Infect Dis. 1987;155(3):45664.

50. Niklasson BS, Jahrling PB, Peters CJ. Detection of Lassa virus antigens and Lassa virus-specific immunoglobulins $\mathrm{G}$ and $\mathrm{M}$ by enzyme-linked immunosorbent assay. J Clin Microbiol. 1984;20:239-44.

51. Stadhouders R, Pas SD, Anber J, Voermans J, Mes THM, Schutten M. The effect of primer-template mismatches on the detection and quantification of nucleic acids using the 5' nuclease assay. J Mol Diagn. 2010;12(1):109-17.

\section{Publisher's Note}

Springer Nature remains neutral with regard to jurisdictional claims in published maps and institutional affiliations.

Ready to submit your research? Choose BMC and benefit from:

- fast, convenient online submission

- thorough peer review by experienced researchers in your field

- rapid publication on acceptance

- support for research data, including large and complex data types

- gold Open Access which fosters wider collaboration and increased citations

- maximum visibility for your research: over $100 \mathrm{M}$ website views per year

At BMC, research is always in progress.

Learn more biomedcentral.com/submissions 